\title{
ACTIVE METHODOLOGIES IN HEALTH EDUCATION FOR THE ELDERLY: a literature review
}

METODOLOGIAS ATIVAS NO ENSINO DE SAÚDE DO IDOSO: uma revisão bibliográfica METODOLOGÍAS ACTIVAS EN EDUCACIÓN SANITARIA PARA PERSONAS MAYORES: una revisión de la literatura

\section{Ana Kleiber Pessoa Borges \\ Biologist, Master and PhD from UNESP / Rio Claro, SP. Professor in the Nursing Graduation at UFT (Federal University of Tocantins, Palmas / TO). anakleiber@uft.edu.br. \\ 0000-0003-1865-2595}

\section{Ana Gabriela Ferreira Brito}

Master's student in Science and Health Teaching (UFT). Graduated in Psychology (CEULP / ULBRA). anagfbrito@gmail.com.

\section{0-0002-8533-7176}

\section{Ilaíse Brilhante Batista}

Master's student in Science and Health Teaching (UFT). Postgraduate degree in Urgency and Emergency / ICU (INESPO). Graduated in Nursing (UFMA). ilaisebrilhante@gmail.com.

0000-0001-5705-5254

\section{Jéssica da Silva Marinho}

Master's student in Science and Health Teaching (UFT). Graduated in Nursing (UFT). jess.smarinho@gmail.com.

0000-0001-8950-7083

\section{Erenilde Barbosa da Silva Costa}

Graduated in Pharmacy (CEULP / ULBRA). erenildebarbosa@hotmail.com.

0000-0001-5188-7930

\section{Mislene Ferreira Xavier de Melo}

Graduada em Enfermagem mislene melo@mail.uft.edu.br.

\section{0-0002-9099-3960}

Correspondence: Federal University of Tocantins. Higher Studies Center in Grajaú. Rua da Mangueira, S / N - Bairro Rodoviário - CEP 65. 940-000 - Grajaú, MA BRAZIL. E-mail: cesgra@uema.br.

Received: 10.12 .2020

Accepted: 11.20 .2020

Published: 01.01.2021.

\begin{abstract}
:
This research aimed to analyze the practices in active methodologies used in health education for the elderly. The sample search was carried out in the LILACS, SCiELO, CAPES journals and Google Scholar search databases. Seven articles were selected and their analysis resulted in the categories "the use of active methodologies for teaching health to the elderly" and "the use of the main active methodologies in the training of academics, professionals and caregivers". Current social demands require teaching methodologies that enable critical, reflective and problematizing training. The need for more research on this topic is suggested, both in the academic sphere and in other teaching contexts, such as health and permanent education.

KEYWORDS Active methodologies; Health; Aged.
\end{abstract}

\section{Introduction}

Population ageing is a phenomenon that has been occurring worldwide and, due to the reduction of the birth rate and the increased percentage of elderly people, the age pyramid is inverted. Other factors that contribute to this effect are the pharmacological and technological discoveries provided by science, thus guaranteeing the population an extended life expectancy (Melo, 2017).

The aging process occurs naturally, irreversibly and is multifactorial (Camarano, 2008; Viana, Monteiro, Barroso \& Rainho, 2013). Customarily, perceptions about aging are loaded with stereotypes, which limit the possibilities of conceiving this portion of the population in all its potential. However, the increase in longevity has provided new 
perspectives for this public, which before was seen only as a social "parasite", but, in the ongoing context, is a subject with greater opportunities to redefine and live his old age vividly (World Organization Health [WHO], 2015).

Therefore, a readjustment in public policies inserting this generation in social contexts is necessary, thus contributing to a new look at old age (Felipe \& Sousa, 2018). In this regard, the Política Nacional da Pessoa Idosa (PNPI) has emphasized nowadays the promotion of healthy aging focused on the development of actions that promote functional capacity, adoption of healthy habits in old age, prevention of risks of falling, functional losses, deficiencies in food and actions that guarantee the reduction of social isolation for the elderly (Veras \& Oliveira, 2018).

Regarding this matter, the PNPI proposes that Higher Education Institutions pay more attention to this audience, promoting, through teaching-learning strategies, the training of professionals trained to act in face of the new scenarios that aging has placed for society, contributing to the development of healthy aging. Consequently, it is necessary to insert subjects that cover the area of Gerontology and Geriatrics in the academic curricula, since these are areas of study dedicated to the aging and health of the elderly (Carvalho, 2015).

In this context, it is understood that the didactics and methodology used in teaching are as important as the contents taught. Traditional education, however, has not kept up with these educational demands, after all, it is ill-fated to expose content and the little involvement of students in the learning processes. Thus, teaching needs to be in tune with the social and educational dynamics, providing, through more participatory methodologies, the development of reflective subjects and consciously involved in the construction of knowledge that is meaningful to modify the contexts in which they are inserted (Paiva, Parente, Brandão \& Queiroz, 2016; Duarte, 2018).

In this regard, Resolution No. 569/2017 provides for the introduction in the Diretrizes Curriculares Nacionais (DCN) for courses in the health area of innovative pedagogical proposals, using diversified methodologies that promote student participation and autonomy, integrating content with the purpose of promoting learning based on action-reflection-action. The DNC should also consider the approach of themes related to population aging and the emergence of chronic non-communicable diseases (NCDs), given the relevance that these issues have achieved in the social, political and health spheres (Ministério da Saúde, 2017).

It is understood, then, that active methodologies have the potential to promote this engaging training, as they underpin teaching-learning in real or simulated situations, aiming to solve problems and inserting the student into multiple realities (Berbel, 2011) . 
Thus, this study aims to analyze the practices in active methodologies used in health education for the elderly between the years 2010 to 2020 .

\section{Method}

In this study, an integrative literature review was made, which consists of a method that allows the analysis of scientific materials from studies already published in a broad and systematic way to generate new knowledge (Neto, Marques, Fernandes \& Nóbrega, 2016).

To carry out the study, the following steps have been followed: definition of the research theme, delimitation of inclusion and exclusion criteria, selection of articles in the databases, categorization of studies, evaluation of pre-selected studies, interpretation of results and presentation of the review.

To get the journals pertinent to the theme, the following online databases have been used, LILACS (Latin American and Caribbean Literature in Health Sciences), SciELO (Scientific Electronic Library Online), CAPES Journals and the search Google Scholarengine (Google scholar) were used.

The descriptors used for the selection were: active methodology, health and elderly, thus generating the following string search: "active methodology" AND elderly AND health, to find studies.

The inclusion criteria established are: publications from 2010 to June 2020 with online availability of the full text, in Portuguese, published in periodicals. Duplicate articles, studies published in conference proceedings, expanded abstracts, books, course completion papers, theses and dissertations were not included.

The search generated 1,403 results, with Google Scholar being the search engine with the highest number of articles returned. Following the inclusion and exclusion criteria, 1,024 articles were removed, leaving 19 papers. After a more in-depth reading, we excluded 08 papers because they did not agree with the proposal of this paper, and finally, 04 more papers were excluded because they were duplicated between platforms. The final sample consists of 07 works. The arrangement of the search procedure is illustrated in Figure 1.

All articles were read in full and individually. The indicators for reasoning and interpretation for the main results arranged in a summary table containing information from each research, with the following topics: year of publication, title, authors, objective, methodology and journals.

For the treatment and interpretation of the results, the data were coded through structural and simultaneous cuts of each article, thus generating nuclei related to the 


\section{Obsevisto}

e-ISSN n² 2447-4266

Palmas, v. 7, n. 1, p. 1-13, jan.-mar., 2021 http://dx.doi.org/10.20873/uft.2447-4266.2021v7n1a10en

analysis of the articles contents. The analysis was performed by categorization, which according to Minayo (1992, apud BARDIN, 2011) Bardin (in Minayo, 1992) consists of the dissemination and classification of the text according to categories grouped analogously. The analysis categories were defined according to the semantic criteria, giving rise to the following thematic categories: "The use of active methodologies for teaching health to the elderly" and "The use of the main active methodologies in the training of academics, professionals and caregivers". Subsequently, we observed divergences and convergences between different authors by interpreting the results obtained.

Figure 1 Systematization for sample selection.

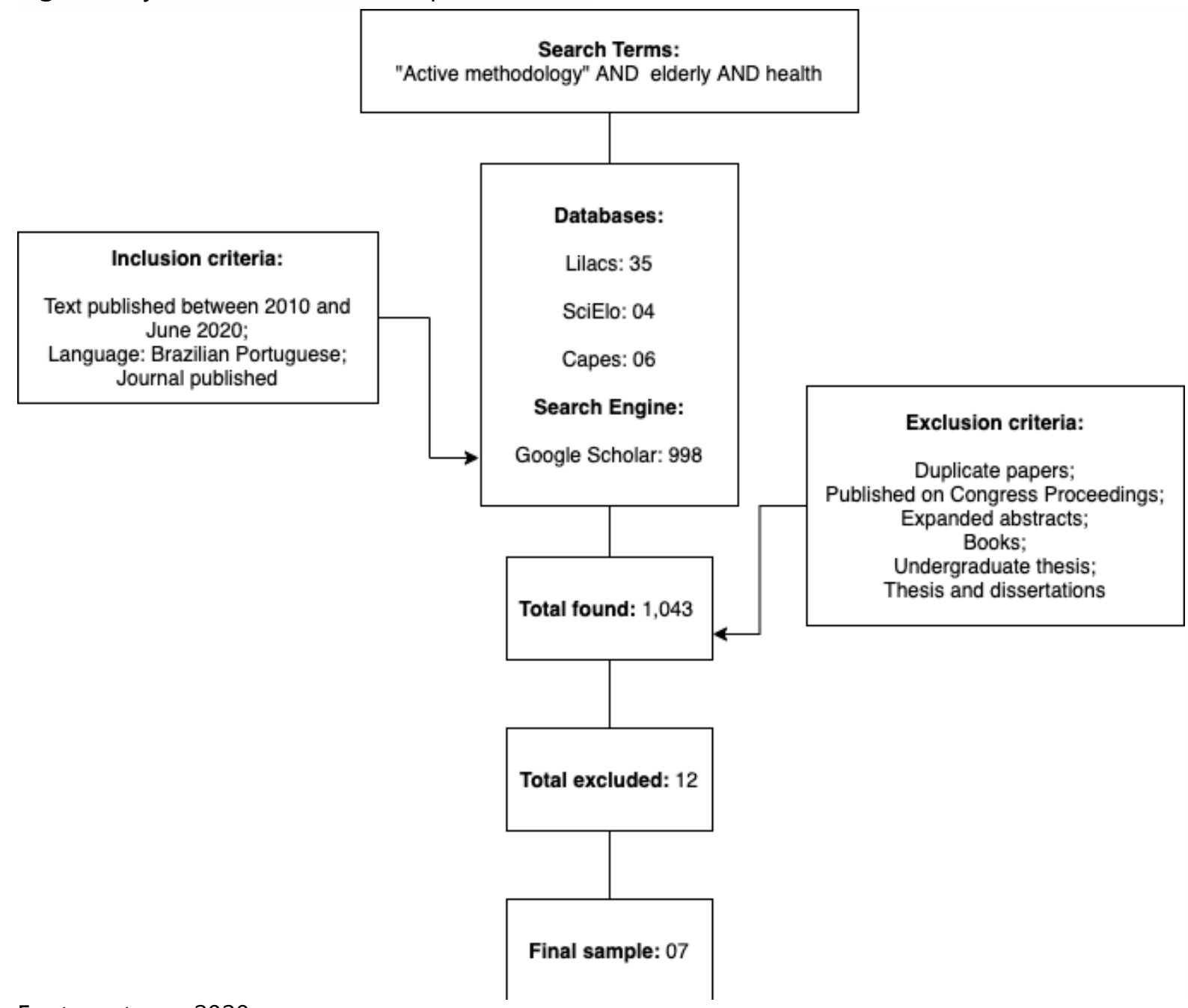

Fonte: autores, 2020.

\section{Results and Discussion}

After searching the databases using the crossing of the descriptors mentioned in the methodology, we obtained the results described in Table 1. 
Table 1 Data of the articles used in this research.

\begin{tabular}{|c|c|c|}
\hline Year & Title & Authors \\
\hline 2013 & $\begin{array}{c}\text { O impacto do estágio na formação do } \\
\text { farmacêutico no cuidado ao paciente } \\
\text { idoso }\end{array}$ & $\begin{array}{c}\text { Alves, M. I. G.; Rios, P. S. S.; Rios, M. } \\
\text { C. }\end{array}$ \\
\hline 2017 & $\begin{array}{c}\text { Estratégias educativas para promoção } \\
\text { da saúde de idosos de um centro de } \\
\text { convivência }\end{array}$ & $\begin{array}{c}\text { Oliveira, F. A., Barros, L. S. F., } \\
\text { Aguiar, F. I. P. F., Gomes, L. F. S., } \\
\text { Guedes, M. V. C., \& Moura, D. J. M. }\end{array}$ \\
\hline 2018 & $\begin{array}{l}\text { Metodologias ativas na graduação em } \\
\text { enfermagem: um enfoque na atenção } \\
\text { ao idoso }\end{array}$ & $\begin{array}{l}\text { Souza, E. F. D.; } \\
\text { Silva, A. G.; } \\
\text { Silva, A. I. L. F. }\end{array}$ \\
\hline 2019 & $\begin{array}{l}\text { Competências e habilidades } \\
\text { desenvolvidas no ensino clínico prático } \\
\text { em saúde do adulto e idoso: relato de } \\
\text { experiência docente }\end{array}$ & $\begin{array}{l}\text { Leite, C. N., Soares, T. C. S., Júnior, } \\
\text { R. J. C. M., Souza, D. V. de, \& Jesus, } \\
\text { M. L. de. }\end{array}$ \\
\hline 2019 & $\begin{array}{l}\text { Contribuições da metodologia da } \\
\text { problematização na formação de } \\
\text { cuidadores de idosos }\end{array}$ & $\begin{array}{l}\text { Pissaia, L. F., Rehfeldt, M. J., Costa, } \\
\text { A. E., Moccelin, J. M., \& Monteiro, S. }\end{array}$ \\
\hline 2019 & $\begin{array}{l}\text { Projetos políticos e pedagógicos de } \\
\text { residência de enfermagem ao idoso na } \\
\text { pesquisa freiriana }\end{array}$ & $\begin{array}{c}\text { Rodrigues, J. M., Menezes, T. M. O, } \\
\text { Rosa, D. O. S., Freitas, A. V. S., \& } \\
\text { Prado, M. L. }\end{array}$ \\
\hline 2020 & $\begin{array}{c}\text { Avaliação do conhecimento e } \\
\text { capacitação dos ACS's acerca do uso da } \\
\text { escala de depressão geriátrica como } \\
\text { forma de triagem de depressão em } \\
\text { idosos cadastrados na ESF do Parque } \\
\text { Verde em Belém-PA }\end{array}$ & $\begin{array}{l}\text { Freitas, C. B. de, Lemos, G. S., } \\
\text { Sousa, F. P. G. de, Oliveira F. F., } \\
\text { Ramos, L. S., Segundo, L. P. S., \& } \\
\text { Fernandes, T. A., et al. }\end{array}$ \\
\hline Year & Title & Authors \\
\hline 2013 & $\begin{array}{c}\text { O impacto do estágio na formação do } \\
\text { farmacêutico no cuidado ao paciente } \\
\text { idoso }\end{array}$ & $\begin{array}{c}\text { Alves, M. I. G.; Rios, P. S. S.; Rios, M. } \\
\text { C. }\end{array}$ \\
\hline
\end{tabular}

Fonte: autores, 2020.

Chart 1 describes the data related to articles published in the LILACS, CAPES journals, Scielo and the Google Scholar search engine, from 2010 to June 2020. With regard to the frequency of publication, the year with the highest index was 2019, with 42.9\% ( $n=3$ ) of the articles. The rest of the work took place in 2013, 2017, 2018 and 2020, all with $14.3 \%(n=1)$.

When analyzing the publication journal, 2 (28.6\%) were published in the Revista Brasileira de Enfermagem, 1 (14.3\%) Teaching Health and Environment, 1 (14.3\%) Brazilian Journal of Health Review, 1 (14,3\%) Graduation Notebooks-Biological and Health Sciences, 1 (14.3\%) Conexão UEPG and 1 (14.3\%) Revista Eletrônica Acervo Saúde.

In relation to the most repeated keywords: "Education in nursing"(7.7\%); "Nursing" (7.7\%); "Elderly" (7.7\%); "Active methodologies" 7.7\%). 
As for the methodology characteristics used in these studies, 3 (42.9\%) are experience reports, 2 (28.6\%) had a qualitative approach, 1 (14.3\%) had a quantitative approach and 1 (14.3) \%) with a mixed approach.

\section{The use of Active Methodologies for Health Education for the Elderly}

Among the social changes that have been observed because of the growing search and insertion of the elderly, in contexts where they were not previously perceived, is education (WHO, 2015). It is known that education offers great potential to promote improvements in the lives of people and society as a whole, since it reduces social inequities, provides health benefits, brings more years of life, in addition to enabling greater political awareness (Pieri, 2018).

"If education alone does not transform society, neither does society change" (Freire, 2000, p. 31). This excerpt from Paulo Freire's Third Pedagogical Letter (2000) guides to an expanded understanding of education, which overcomes limits of the classroom and articulate in the political, ethical, social and individual multiplicity, in order to contribute to the construction of meaningful knowledge and acts as a factor of change (Andreola, 2011).

Freire, in his pedagogical contributions, prompted the discussion about banking education and liberating education. The first is characterized as an act of depositing, where an anti dialogical relationship is established between educator-student. The second is constituted through action-reflection, dialogue and the search for man to recognize himself in the world, with the world and with others (Freire, 1987). The idea is that educational practice extends a horizon beyond a strictly vertical approach, with no space for valuing the knowledge of learners, harming the potential that education has to unlock.

In this sense, taking into account the elderly public and their need for insertion in the education scenarios, the National Policy for the Elderly, in the third item of article ten, describes government actions in the area of education, in which it provides: (a) adaptation of curricula, methodologies and teaching material for educational programs for the elderly; (b) insertion of content aimed at aging at diverse levels of formal education; (c) inclusion of Gerontology and Geriatrics as curricular subjects in higher education courses; (d) development of educational programs that inform the population about the aging process; (e) development of programs that adopt distance learning modalities suitable for the elderly; ( $f$ ) encouraging the creation of universities opens to the elderly as a way of universalizing access to alternative forms of knowledge (Brasil, 1994). 
Similar to the National Elderly Policy, the Elderly Statute provides for the right to "education, culture, sport, leisure, entertainment, shows, products and services that respect their peculiar age condition" (Brasil, 2003, art. 20) . In addition to reinforcing some rights already described in the National Policy for the Elderly, it also includes the insertion of content related to technological advances aimed at integration into modern society. Because of this context, education adopts pedagogical strategies, with the objective of socializing knowledge and contributing to the formation of subjects, considering the different human relationships.

Among the strategies employed, the active methodologies stand out, which could be used in two of the seven articles selected for this review. In the study by Alves, Rios and Rios (2013), it was highlighted the use of active methodologies based on problems, by academics in the Pharmacy course, for the education of the elderly about the correct use of medications, medicinal plants, harmful effects of self-medication and educational actions focused on the benefits of correct food. For the effectiveness of the methodology, a playful activity based on games was implemented, in order to contribute to the development of learning.

At this stage, the use of active methodologies in line with the practice of educational actions is verified, thus, health education works as a contribution to prevent injuries, promote and recover health in search of the quality of life of individuals and the community, through technical and popular knowledge. Understanding the public to which efforts to promote health education are directed present a challenge for those who are in the process of training and for health professionals, managers and the community.

Similarly, the study by Oliveira et al (2017) proposes pedagogical strategies by nursing students with a methodological perspective based on the dialogical education practices proposed by Paulo Freire. The research in question additionally uses the problematization methodology, proposing a care technology based on playful activities and group techniques.

In this sense, it is comprehensible that educational actions aimed at the practice of recreational activities with the elderly population bring several benefits and encourage independence and autonomy. Such practices influence psychological, biological and social aspects (Fleurí et al., 2013). Cyrino, Silva, Souza, Borges, \& Pereira (2016) also state that such activities provide the elderly with a feeling of belonging to the health-disease process, as well as the contribution to cognitive and functional performance. Ultimately, they conclude that playful practices give meaning to the process of building learning and promoting health. 
Silva et al. (2017), in their study on educational actions with the elderly, corroborate the studies by Oliveira et al. (2017) and Alves et al. (2013), reaffirming the importance of using active methodologies through the use of games, theaters, tours, among others. These teaching practices contribute to the learning process, adding benefits to the formation of the individual in its multiple aspects. In this way, education enhances the value of the human being, playing a role in influencing individual and collective needs, in addition to acting in the promotion of health and prevention of pathologies. To this degree, activities like these generate beneficial effects on the health of the elderly, contributing to their healthy aging and their insertion in Society.

\section{The use of the main Active Methodologies in the Formation of Academics, Professionals and Caregivers}

Educational practices change over time. Education, in the twentieth century, was strongly influenced by thinkers such as Frenet, Monterrosi, Piaget, Vygotsky and Paulo Freire, who introduced discussions aimed at teaching practices that would provide students with autonomy (Farias, Martins \& Cristo, 2015).

For Freire (1987), education is the transforming basis of society, because in his book Pedagogia do Oprimido, he quotes "it is not in silence that men make themselves, but in words, at work, in action-reflection. Education alone does not transform society, neither does society change." (p.50). In this sense, it can be comprehended that education must be combined with dialogue to build a critical, reflective and questioning being. For the author, knowledge is produced "in invention, in reinvention, in the restless, impatient, permanent search that men do in the world, with the world and with others" (Freire, 1987).

Given this idea, the use of active methodologies is essential for the construction of modern pedagogical perspectives. They provide students with unusual insights that enable them to adopt an active stance in order to build learning in an autonomous, engaged manner, stimulating the search for meaningful, reflective knowledge that is useful for the transformation of their social context (Colares \& Oliveira, 2018; Diesel, Baldez \& Martins, 2017).

Through active methodologies, Souza, Silva and Silva (2018), report the benefits that such practices provide to students, providing insertion in simulated environments that encourage them to act in the face of problems, thus developing security and selfconfidence for subsequent professional practice. The authors conclude these practices enrich the teaching-learning process of academics, providing opportunities for the formation of a perspective that allows to meet the needs of the subjects in a holistic way. Academic training, despite having in essence the cognitive understanding of concepts 
and procedures, develops in a context of interaction in which one learns with the other, in exchange processes that involve the body, language and especially, the principles on which such manifestations are based.

In this sense, the study by Leite, Soares, Júnior, Souza and Jesus (2019) addresses the experiences of professors of the nursing course, in a discipline aimed at the adult and elderly public. In this study, they highlighted the possibility of developing competencies and skills in practical teaching of undergraduate courses based on activities proposed by the discipline, making it possible to approach several themes that enable the relationship between theory-oriented practice.

In the study by Rodrigues, Menezes, Rosa, Freitas and Prado (2017), the results evidenced point to the re-elaboration of Pedagogical Political Projects (PPPs) for nursing homes. Twelve PPPs were analyzed, in which the aspects related to the problematizing, humanistic and dialogical dimensions proposed by the study, were sometimes unincluded in all PPPs. Only one of the PPPs encompassed all three dimensions, as it provided residents with scenarios that enable the development of a reflective and active posture through real situations, permeated by humanized, ethical and dialogue-based attitudes.

Thus, the experiences of Souza et al. (2018) and Leite et al. (2019) corroborate the study by Rodrigues et al. (2017), the sense of consolidating academic practices with theoretical political support that guarantees the practical execution of these methodologies. Taking into account that the Pedagogical Political Project is the document that conducts the teaching actions of undergraduate courses, it is grasped that both student and teacher practice should be included and supported by the course PPPs.

However, eventually, the Projects do not address all the demands of pedagogical practices perceived in academic or professional practice. It is important to emphasize the use of active methodologies does not depend only on the restructuring of the curricula of the courses, which sometimes have superficial and fragmented designs. Therefore, the teaching posture is a crucial point for the development of methodological objectives that must be aligned with its original pedagogical principles, as this commitment to promoting teaching in an aligned manner ensures the effectiveness of the use of several active methodologies (Simon, Jezine, Vasconcelos \& Ribeiro, 2015).

Taking into account the results found in this study, Pissaia, Rehfeldt, Costa, Moccelin and Monteiro (2019) affirm the use of the problematization methodology for the training of elderly caregivers in a vocational school. Through problematization, caregivers were able to view the training path and the characteristics necessary for the professional, reflecting on the practices of the care process in a critical way, thus visualizing the main errors and successes that occur in relation to this profession. 
It was observed that in most of the articles in the sample, the key pedagogical trends addressed turned to the use of the problematization methodology. The ideas present in the articles found had problematizing principles linked to ludic activities like games, theater and simulations, awakening students and health professionals to assume the main role in the construction of their teaching and learning in an active and autonomous way, thus emphasizing the main essence of the use of these methodologies. It is also verified in the study by Paiva et al (2016), that problematization acts in the transformation of knowledge, since its proposal is based on the resolution of problems that lead the individual to think and insert themselves in the problematic context in a way to build meaningful knowledge.

For Freitas et al. (2020) the use of the active methodology was applied to the knowledge of the CHWs of a team of the Family Health Strategy (ESF) about the use of the depression scale in the elderly. The study was carried out in phases, allowing the monitoring of the knowledge relationship of the $\mathrm{CHA}$ before and after employing the methodology. In the first phase, a knowledge questionnaire was applied on the subject; in the second phase, the participants answered three questions, followed by a lecture. In the third phase, another questionnaire was applied to reassess the knowledge acquired after the explanation. It was evidenced that there was a significant improvement in the knowledge of the participants, emphasizing the use of this tool becomes increasingly effective for health education.

It is important to highlight that the study mentioned above does not bear the name of the applied methodology, using traditional techniques like expository lecture and application of questionnaires for the development of the methodology. Due to this type of experience, Sobral and Campos (2012) cite in their study, that some practices evidenced in the articles were also linked to traditional methodologies linked to conservative education, however, due to the use of dynamism for teaching, they were characterized as active methodologies. Thus, it is understood the need to unite and base the active methodologies with the theories of knowledge, since some techniques that are considered innovative are just improved old methodologies.

\section{Final Considerations}

This systematic review analyzed the practices in active methodologies used in health education for the elderly. Among the results obtained, it can be noted in some of the studies, that the active methodological practices were actually uncontemplated. The appropriation of the use of these, at times, was perceived as a mistaken dissemination of active methodologies, through traditional teaching. 
It was noted that with the increase in population aging, it is necessary for health training to add practices aimed at new contexts, considering the modern social demands. In the academic environment, approaches made through active methodologies favor professional insertion, enabling students to develop critical thinking, autonomy and engagement, which will contemplate this practice.

In view of the works presented, it is suggested the need for more research regarding the use of active methodologies aimed at teaching health care to the elderly, both in the academic sphere and in other teaching contexts, like health and permanent education.

\section{References}

ALVES, M. I. G.; RIOS, P. S. S.; RIOS, M. C. (2013). O impacto do estágio na formação do farmacêutico no cuidado ao paciente idoso. Cadernos de Graduação - Ciências Biológicas e da Saúde. v. 1, n. 2.

ANDREOLA, B. A. (2011). Por uma pedagogia das grandes urgências planetárias. Educação. Santa Maria, v. 36, n. 2, p. 313-30.

BARDIN, L. Análise de Conteúdo. (2011). NETO, L. A.; PINHEIRO, A. (trad.). Ed. 70.

BERBEL, N. A. N. (2011). As metodologias ativas e a promoção da autonomia de estudantes. Semina: Ciênc. Sociais e Humanas. v. 32, n. 1, p. 25-40.

BRASIL. (2017, dez 08). Ministério da Saúde. Conselho Nacional de Saúde. Resolução $n^{\circ}$ 569.

BRASIL. Lei no 8.842, Política Nacional do Idoso. (1994). DF, v. 132, n. 3, p. 1-3.

BRASIL. Lei no 1.074, Estatuto do Idoso. (2003). DF.

CAMARANO, A. A. A. (2008). demografia e o envelhecimento populacional. In: FUNDAÇÃO OSWALDO CRUZ. Escola Nacional de Saúde Pública Sergio Arouca. Educação a Distância. Envelhecimento e saúde da pessoa idosa. Borges, A. P. A. Coimbra, A. M. C. (org.). Rio de Janeiro: EAD/ENSP, 340 p.

CARVALHO, C. R. A. (2015). A Saúde do Idoso no ensino superior de universidades públicas do Rio de Janeiro: o caso dos cursos de Educação Física, Enfermagem e Nutrição. Tese (doutorado). $85 \mathrm{f}$.

CACHIONI, M.; TODARO, M. A. (2016). Política nacional do idoso: reflexão acerca das intenções direcionadas à educação formal. In: ALCÂNTARA, A. O.; CAMARANO, A. A.; GIACOMIN, K. C (eds.). Política Nacional do Idoso: velhas e novas questões. Rio de Janeiro: IPEA. p.457-78.

COLARES, K. T. P.; OLIVEIRA, W. (2018). Metodologias ativas na formação profissional em saúde: uma revisão. Revista Sustinere. RJ, v. 6, n. 2, p. 300-20.

CYRINO, R. S. et al. (2016). Atividades lúdicas como estratégia de educação em saúde com idosos. Rev. Ciênc. Ext. v. 12, n. 3, p. 154-63.

DIESEL, A.; BALDEZ, A. L. S.; MARTINS, S. N. (2017). Os princípios das metodologias ativas de ensino: uma abordagem teórica. Revista Thema. v. 14, n. 1.

DUARTE, S. M. Os impactos do modelo tradicional de ensino na transposição didática e no fracasso escolar. Dissertação (mestrado). 2018. $121 \mathrm{f}$.

FARIAS, P. A. M.; MARTIN, A. L. A. R.; CRISTO, C. S (2015). Aprendizagem Ativa na Educação em Saúde: Percurso Histórico e Aplicações. Rev. bras. educ. med. [online]. vol.39, n.1, pp.143-150.

FELIPE, T. W. S. S.; SOUSA, S. M. N (2018). Gênero e geração: os significados atribuídos à velhice e o que torna possível a distinção entre os sujeitos definidos como idosos. Cad. Eletrônico de Ciências Sociais: Cadecs, v. 6, n. 2, p. 32-53. 
FLEURÍ, A. C. P. et al. (2013). Atividades lúdicas com idosos institucionalizados. Rev. Enfermagem Revista. v. 16. n. 01. jan-abr.

FREIRE, P. Pedagogia do oprimido (1987). Paz e Terra. RJ, 17ª ed. 107 p.

FREITAS, C. B. et al. (2020). Avaliação do conhecimento e capacitação dos agentes comunitários de saúde acerca do uso da escala de depressão geriátrica como forma de triagem de depressão em idosos cadastrados na ESF do Parque Verde em Belém do Pará. Braz. J. Hea. Rev. Curitiba, v. 3, n. 2, p. 2342-2354.

LEITE, C. N. et al. (2019). Competências e habilidades desenvolvidas no ensino clínico prático em saúde do adulto e idoso: relato de experiência docente. REAS/EJCH v. sup. 29, e1341.

MINAYO, M.C.S (1992). O desafio do conhecimento: pesquisa qualitativa em saúde. $5^{a}$ ed. São Paulo: Hucitec.

MELO, F (2017). Envelhecer não é um fardo. Rio de Janeiro: Radis, v. 173, p. 22.

MENEZES, M. G.; SANTIAGO, M. E (2014). Contribuição do pensamento de Paulo Freire para o paradigma curricular crítico-emancipatório. Pro-Posições, v. 25, n. 3, p. 4562.

NETO, J. M. R. et al. (2016). Análise de teorias de enfermagem de Meleis: revisão integrativa. Rev Bras Enferm [Internet]. v. 69, n. 1, p. 174-81, jan-fev.

OLIVEIRA, F. A. et al. (2017). Estratégias educativas para promoção da saúde de idosos de um centro de convivência. Revista Conexão UEPG. v. 13 n. 3, set-dez.

ORGANIZAÇÃO MUNDIAL DE SAÚDE. (2015). Relatório mundial de envelhecimento e saúde. 28 p.

PAIVA, M. R. F. et al. (2016). Metodologias ativas de ensino-aprendizagem: revisão integrativa. Sanare. Sobral, v. 15, n. 02, p. 145-153, jun-dez.

PIERI, R. (2018). Retratos da educação no Brasil. Instituto de Ensino e Pesquisa.

PISSAIA, L. F. et al. (2019, abril). Contribuições da metodologia da problematização na formação de cuidadores de idosos. Ensino, Saúde e Ambiente. v. 12, n. 1, p. 143159.

RODRIGUES, J. M. et al. (2019). Projetos políticos e pedagógicos de residência de enfermagem ao idoso na perspectiva freiriana. Rev Bras Enferm. v. 72, Suppl 2, p. 41-7.

SILVA, W. et al. (2017). Ações educativas vivenciadas com idosos: Um relato de experiência. Rev. Ciênc. da Saúd Nova Esperança, v. 15, n. 3, p. 31-36.

SIMON, E. et al. (2015). Metodologias ativas de ensino-aprendizagem e educação popular: encontros e desencontros no contexto da formação dos profissionais de saúde. Interface-Comunic., Saúde, Educação, v. 18, p. 1355-1364.

SOBRAL, F. R.; CAMPOS, C. J. G. (2012). Utilização de metodologia ativa no ensino e assistência de enfermagem na produção nacional: revisão integrativa. Rev Esc Enferm USP. v. 46, n. 1, p. 208-18.

SOUZA, E. F. D.; SILVA, A. G.; SILVA, A. I. L. F. (2018). Metodologias ativas na graduação em enfermagem: um enfoque na atenção ao idoso. Rev. Bras. Enferm. Brasília, v. 71 , supl. 2, p. 920-924.

VERAS, R. P.; OLIVEIRA, M. (2018). Envelhecer no Brasil: a construção de um modelo de cuidado. Ciênc. \& Saúd. Colet. RJ, v. 23, n. 6, p. 1929-1936.

VIANA, C. et al. (2013). Capacidade funcional de idosos do concelho de Baião. In: SOUZA, D. N.; RUA, M. S. (coord.). Cuidadores informais de Pessoas idosas: caminhos de mudança. Aveiro: UA Editora. p. 320-25.WODAK, R., \& MEYER, M. (2001). Methods of Critical Discourse Analysis. Londres: Sage Publications 


\section{arevisto Observatório}

\section{RESUMO:}

Esta pesquisa objetivou analisar as práticas em metodologias ativas utilizadas no ensino de saúde do idoso. Realizou-se a busca da amostra nas bases de dados LILACS, SciELO, Periódicos CAPES e buscador Google Scholar. Foram selecionados 07 artigos e sua análise resultou nas categorias "o uso de metodologias ativas para o ensino em saúde ao idoso" e "o uso das principais metodologias ativas na formação de acadêmicos, profissionais e cuidadores". As demandas sociais atuais exigem metodologias de ensino que possibilitem uma formação crítica, reflexiva e problematizadora. Sugere-se a necessidade de mais pesquisas sobre esse tema, tanto no âmbito acadêmico, quanto em outros contextos de ensino, como a educação em saúde e permanente.

PALAVRAS-CHAVE: Metodologia ativa; Saúde; Idoso.
e-ISSN n ${ }^{\circ} 2447-4266$

Palmas, v. 7, n. 1, p. 1-13, jan.-mar., 2021 http://dx.doi.org/10.20873/uft.2447-4266.2021v7n1a10en

\begin{abstract}
RESUMEN:
Esta investigación tuvo como objetivo analizar las prácticas en metodologías activas utilizadas en la educación sanitaria para los ancianos. La muestra se buscó utilizando las revistas LILACS, SciELO, CAPES y Google Scholar. Se seleccionaron siete artículos y su análisis dio como resultado las categorías "el uso de metodologías activas para enseñar la salud a los ancianos" y "el uso de las principales metodologías activas en la formación de académicos, profesionales y cuidadores". Las demandas sociales actuales requieren metodologías de enseñanza que permitan una capacitación crítica, reflexiva y problemática. Sugerimos la necesidad de más investigación sobre este tema, tanto en el ámbito académico como en otros contextos de enseñanza, como la salud y la educación permanente.
\end{abstract}

PALABRAS-CLAVES: Metodologías activas; Salud; Anciano. 